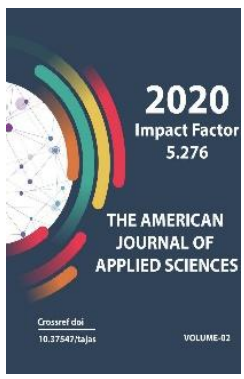

\title{
Language Development Is Changing
}

\author{
Usmonova Mehriniso Umarovna \\ Lecturer, Termez State University, Termez, Uzbekistan.
}

Journal Website:

http://usajournalshub.c

om/index,php/tajas

Copyright: Original content from this work may be used under the terms of the creative commons attributes 4.0 licence.

\section{ABSTRACT}

This article deals with main language problem. Language is a constantly changing, progressive social phenomenon. Language development is directly related to the development of society. The progress of the language is first and foremost reflected in its dictionary wealth.

\section{KEYWORDS}

Language, development, useful, according to, phonetix.

\section{INTRODUCTION}

Changes in people's lives, the progress of Science and culture enrich the lexicon. And the sound system of the language and the construction of the grammatics change very slowly. This can be noticed through the study of the history of the language. This foundation serves as a starting point for the origin of a new science. The primary aim of the investigation is to prove that the language stands into the close contact with culture and history. Consequently their synchronic research would be very useful for language education. The goal of teaching speaking skills is communicative efficiency. Learners should be able to make themselves understood, using their current proficiency to the fullest. They should try to avoid confusion in the message due to faulty pronunciation, grammar, or vocabulary, and to observe the social and cultural rules that apply in each communication situation. To help students develop communicative efficiency in speaking, instructors can use a balanced activities approach that combines language input, structured output, and communicative. Language input comes in the form of teacher 
talk, listening activities, reading passages, and the language heard and read outside of class. It gives learners the material they need to begin producing language themselves. Language input may be content oriented or form oriented.

Content-oriented input focuses on information, whether it is a simple weather report or an extended lecture on an academic topic. Content-oriented input may also include descriptions of learning strategies and examples of their use.Formoriented input focuses on ways of using the language: guidance from the teacher or another source on vocabulary, pronunciation, and grammar (linguistic competence); appropriate things to say in specific contexts (discourse competence); expectations for rate of speech, pause length, turn-taking, and other social aspects of language use (sociolinguistic competence); and explicit instruction in phrases to use to ask for clarification and repair miscommunication (strategiccompetence). In the presentation part of a lesson, an instructor combines content-oriented and form-oriented input. The amount of input that is actually provided in the target language depends on students' listening proficiency and also on the situation. For students at lower levels, or in situations where a quick explanation on a grammar topic is needed, an explanation in English may be more appropriate than one in the target language. Structured output focuses on correct form. In structured output, students may have options for responses, but all of the options require them to use the specific form or structure that the teacher has just introduced.

Structured output is designed to make learners comfortable producing specific language items recently introduced, sometimes in combination with previously learned items. Instructors often use structured output exercises as a transition between the presentation stage and the practice stage of a lesson plan. textbook exercises also often make good structured output practice activities.

In communicative output, the learners' main purpose is to complete a task, such as obtaining information, developing a travel plan, or creating a video. To complete the task, they may use the language that the instructor has just presented, but they also may draw on any other vocabulary, grammar, and communication strategies that they know. In communicative output activities, the criterion of success is whether the learner gets the message across.

\section{MATERIALS AND METHODS}

The Uzbek language is the language of the Uzbek nation, the Uzbek language is the state language of the Republic of Uzbekistan. The status of the Uzbek literary language as a state language has grown incomparably, the scope of Service has expanded, the composition of the dictionary has become rich, there have been great changes in the improvement of the phonetic system and grammatical construction.

The Uzbek national language is the common and unique language of all people of the present Uzbek nationality. It is directly connected with the formation of the Uzbek nation. Until the formation of the Uzbek nation, it lived and developed in the style of the language of the seed, the language of the tribe and the language of the people (elat).

As a result of the social function of the Uzbek literary language, serious changes took place in its dictionary structure. It is worth considering that the lexical of the language is enriched by internal possibilities on account of newly formed words and accepted words from other languages. Many changes in the socio-economic life of people, in the national economy, in the sphere of Culture, Science and technology have brought out new concepts, new relations. All this led to the fact that the Uzbek language lexicon is rich in 
many new words, as well as in the calculation of borrowed words from other languages. For example: broker, dealer, makler, computer, manager, Farmer, Business, etc. Changes in the meaning of certain Uzbek words have taken place, they began to be used in other meanings. For example: business and entrepreneurial words previously belonged to the adjective category, denoting a sign, at the moment these words have passed to the noun category and have the meaning of the personalaydigan. All these processes have brought the wealth of the Uzbek language dictionary to a new level. Certain changes occurred in the phonetic system of the Uzbek language, as well as in the construction of grammatics.

Gram in the construction of the complex, the agreed forms, the meaning and function of some assistants expanded, the norms of coherent management and support management were established. Word combinations based on Horse Management began to be used more.

\section{RESULT AND DISCUSSION}

The further development of the Uzbek language will continue in connection with the further enrichment of the lexicon and the further improvement of the construction of structures on the basis of internal laws.

National language and its components

It is known that the Uzbek people are one of the ancient peoples of Central Asia, its language began to form in the XI-XII centuries as a people's language according to certain socio-historical conditions and gradually developed.

The language used by all people of Uzbek nationality, regardless of where they live, is called the national (universal) Uzbek language. National language in its composition includes such group of words as literary language, dialect, colloquial speech, jargon, vulgarism (colloquial, Crow's words), varvarism (foreign words that are used without a place in the language).

1. From the phonetic (that is, sound) point of view: no - Zhuk, came - geldi, spring bohor.

2. From a lexical (IE word) point of view: father - ada, Sparrow - secha, Cow - Cow.

3. Grammatically (that is, suffixes and sentence construction): coming (ad.)Kevatti-kelapti-kelotti.

There is only an oral form of folk dialect.

Groups of syllables that are close to each other are called dialects (the dialect suffix denotes the concepts of dialect and dialect together.).In particular, there are three dialects (dialects) of the Uzbek national language:

1. The Karluk dialect (south-eastern group).

2. Kipchak dialect (south-west group).

3. Oghuz dialect (North-West Group).

The Karluk dialect mainly includes urban dialects (Tashkent, Andijan, Fergana, Samarkand, Bukhara). Important phonetic and morphological signs of these syllables are:

1) the sound $k$ at the end of the word is pronounced in the style of y: sieve-elay, Poplar-teray

2) o lashish will happen: brother, nahor nohor.

3) in this dialect, the suffix of the accusative case is absent, and instead of it, the suffix of the accusative case is also used: my brother(ng) notebook.

Kipchak dialects exist in all regions of Uzbekistan, they are mainly distributed in villages (Samarkand, Jizzakh, Surkhandarya, Karakalpakstan, Northern Khorezm regions, toshovuz region of Turkmenistan). Symptoms are as follows:

in place of $y, j$ is used: road - jel, no - jel. 
1) 2)in place of $g, v$ is used: Mountain-tov, so-sov and so on.

2) at the end of the word k, q is reduced to tavushlari: $\operatorname{dry}(q)$, yellow(q).

The Oguz dialect includes several dialects in Southern Khorezm (Urgench, Khiva, Khan, Hazorasp, Koshkopir, Shuvot districts). Symptoms:

a. vowels are pronounced short and oblong: at (Animal), AED (name).

b. $t$ sounds $d$, and $k$ are pronounced in the style of g: mountain - stain, came - galdi.

c. the suffix -in the style of-ing, the suffix-E is pronounced in the style of-a, - na: to the groin-to the groin, alina (to the hand).

\section{CONCLUSION}

For the current Uzbek literary language, Fergana-Tashkent dialects, which are part of the qarluq dialect, are taken as the basis. According to scientists, the Tashkent dialect was phonetically, the Fergana dialect was morphologically based on the literary language. In general, the literary language relies on all dialects.

The concepts of national language and literary language are not the same. If the national language appears with the arrival of the nation on the field, then the literary language occurs even before the national language, when the people's language exists.

\section{REFERENCES}

1. Hajiyev A. Explanatory Dictionary of linguistic terms. - T.: Teacher, 1985.

2. Mengliyev B. The current language of Uzbek literature. - Against: Nasaf, 2005.

3. Ne'matov H., Bazarov A. Language and speech. - T.: Teacher, 1989.

4. Thank Youullayev Sh. Explanatory phraseological Dictionary of the Uzbek language. - T.: Teacher, 1978.
5. Thank Youullayev Sh. Etymological Dictionary of the Uzbek language. - T.: University, 2000.

6. Explanatory Dictionary of the Uzbek language. - M.: Russkiy yazik, 1981.

7. Baranov O.S. Ideograficheskiy slovar russkogo yazika. - What?: Preyey, 1990.

8. Begmatov E.A. Lexical layers of the current Uzbek literary language. - T.: Science, 1985.

9. Tixonov A.What?, Khatamov N.The T. Russiansko-uzbeksky Knight. - What?: Teacher, 1979. 